Available online at: http://ejournal-balitbang.kkp.go.id/index.php/ifrj
e-mail:ifrj.puslitbangkan@ gmail.com
INDONESIAN FISHERIES RESEARCH JOURNAL
Volume 22 Number 1 June 2016
p-ISSN: 0853-8980
e-ISSN: 2502-6569

\title{
ROLE OF SUB SURFACE TEMPERATURE, SALINITY AND CHLOROPHYLL TO ALBACORE TUNA ABUNDANCE IN INDIAN OCEAN
}

\author{
Dian Novianto*1 and Eko Susilo ${ }^{2}$ \\ ${ }^{1}$ Research Institute for Tuna Fisheries, Mertasari Road No. 140, Sidakarya, South Denpasar, Bali, 80223-Indonesia \\ ${ }^{2}$ Institute for Marine Research and Observation New Perancak Road, Jembrana Bali 82251-Indonesia \\ Received; March 07-2016 Received in revised from April 18-2016; Accepted April 22-2016
}

\begin{abstract}
The swimming layer is one of the important factors to get maximum catches, especially on tuna longline effort. The vertical abundance of the albacore tuna was investigated based on catch data and 3 - DINDESO Ocean Model data, such as sub-surface conditions of sea water potential temperature (Temp), salinity (Sal) and mass concentration of diatoms and flagellates expressed as chlorophyll (Chl) in the Eastern Indian Ocean period 2014-2015. Combining the statistical method of generalized additive model (GAM) was performed to analysis in this study. There were seven GAM models that generated with the number of ALB vertical abundance as a response variable, and Temp, Sal, and $\mathrm{Chl}$ as predictor variables. Sal has highly significant $(P<0.001)$ while $\mathrm{Chl}$ and Temp significant $(P<0.01)$ to ALB vertical abundance. Deduced from GAMs, indicated that a negative effect of Sal on the number of ALB was observed at salinity $>34.52 \mathrm{psu}$. There was a positive effect of salinity on the number of ALB, which was from 34.30 to 34.47 psu and Chl showed a positive effect of this variable on the number of ALB caught occurred between $0.01 \mathrm{mg} / \mathrm{m}^{3}$ and $0.12 \mathrm{mg} / \mathrm{m}^{3}$ in the region of high confidence level where negative effect on $>0.13 \mathrm{mg} / \mathrm{m}^{3}$. While ALB catches abundance varied in the temperature range with the highest frequency at $24.0-24.9^{\circ} \mathrm{C}$. Sal was the most important environmental variable to the number of ALB vertically caught, followed by Chl and Temp.
\end{abstract}

\section{Keywords: Albacore tuna; abundance;subsurface; temperature; salinity; chlorophyll; Indian Ocean}

\section{INTRODUCTION}

Albacore tuna (Thunnus alalunga) called ALB, is one of the main target species of the commercial tuna fishery. It is a highly migratory, widely distributed species in the temperate and tropical waters of all oceans and the Mediterranean Sea (Collette \& Nauen, 1983; Yeh et al., 1996; Nishida \& Tanaka, 2008; Wu et al., 2009). In the Indian Ocean ALB was caught almost exclusively under drifting longlines $(98 \%)$ with remaining catches recorded under purse seines and other gears (IOTC, 2007; Nishida \& Tanaka, 2008). According to Schaefer (2001), ALB is considered one of only four tuna species being truly migratory and undertaken seasonal migrations to specific feeding and spawning areas (along with southern, Pacific and Atlantic Bluefin tunas). In Indian Ocean ALB is distributed following a north-south seasonal migration. Immature fish were mainly distributed in areas south of $30^{\circ} \mathrm{S}$ and matures concentrated between $10^{\circ} \mathrm{S}$ to $25^{\circ} \mathrm{S}$, where oceanographic conditions preferred by different developmental stages of ALB in the Indian Ocean were compatible with the Pacific Ocean (Chen et al., 2005).

ALB, being negatively buoyant in seawater, must swim continuously to maintain their position in the water column (Dotson, 1976), due to the swimming layer as one of the important factors to get maximum catches, especially on tuna longline effort. The different characteristic of those oceanographic variabilities each water column influences on fish distribution. Fish will choose a more suitable habitat for feeding, shelter, reproduction and migration (Palacios et al., 2006).

According to Irianto et al. (2015), the national catch of ALB was slightly decreased for $8 \%$ in 2014 compare to 2013 catch. Although the Indian Ocean is one of 
the most productive fishing grounds and has a long history of tuna exploitation, little is known about the oceanographic conditions affecting the distribution and abundance of ALB in those waters. Previous studies showed that environmental factor is the most important parameter ALB abundance in the Indian Ocean (Lan et al., 2012; Chen et al., 2005, Sukresno et al., 2014, Arrizabalaga et al., 2015), but the related literature of ALB in the Indian Ocean is scarce in comparison with other oceanic basins like the Atlantic and Pacific Oceans.

Generalized additive modelling (GAM) (Hastie \& Tibshirani, 1986) is one such method which provides an objective way for the prediction of species abundance based on the known ecology over a large geographic area. It is a semi-parametric approach which can predict non-linear responses to selected predictor variables. Previous studies showed that GAMs can explain the fisheries data and environmental variables and enhance our understanding of ecological systems (Zainuddin et al., 2006, 2008, 2013; Song et al., 2009, 2010; Syamsuddin et al., 2013; Setiawati et al., 2015; Solanki et al., 2015).

The current work investigated the relationships among the vertical abundance of ALB, sub-surface conditions of sea water potential temperature (Temp), sub-surface conditions of salinity (Sal) and subsurface mass concentration of diatoms and flagellates expressed as chlorophyll (Chl) in each hook depth of ALB caught.

\section{MATERIALS AND METHODS Study Area}

The study area in the Eastern Indian Ocean (EIO) was from $-14^{\circ} \mathrm{S}$ to $-2^{\circ} \mathrm{S}$ and $92^{\circ} \mathrm{E}$ to $121^{\circ} \mathrm{E}$ (Figure 1). This area is a highly productive region, the EIO that comprises extensive fishing grounds because of that so many Indonesian longline fleets operated throughout the year in this location.

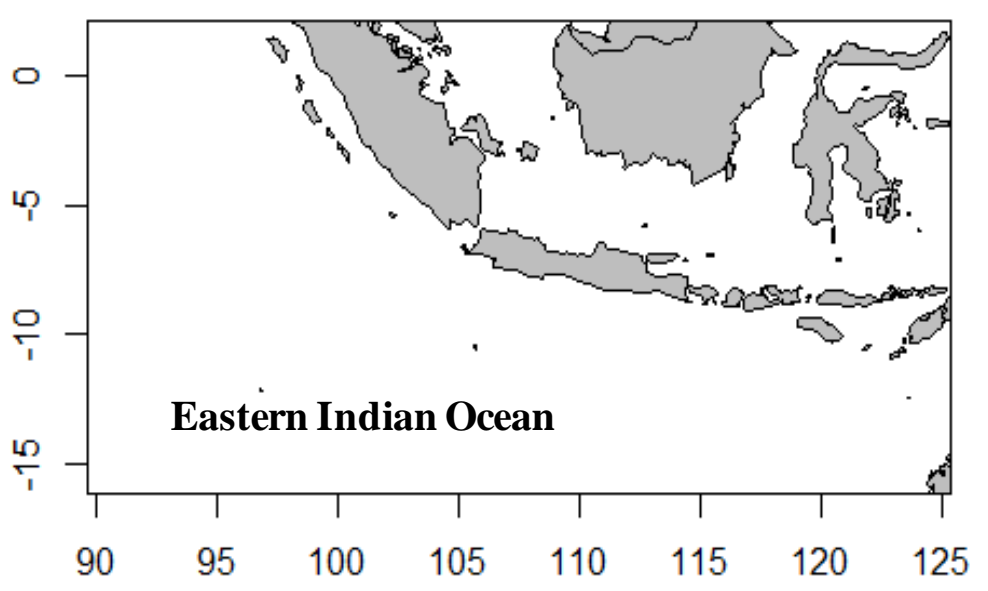

Figure 1. The study area in Eastern Indian Ocean (EIO).

\section{Fishery Data}

Data sets for ALB catch from January 2014 to December 2015 were used to investigate the relationship between ALB abundance with vertically oceanographic parameters in the EIO. The daily ALB fishing was based on the number of branch line longline fishing gears, fishing effort and fishing position in latitude and longitude obtained from scientific observer program RITF (Research Institute for Tuna Fisheries) from 10 longline fishing operation. These data were extracted to obtain the geographic information where the ALB were caught, time when the fishing operation and number individual ALB which caught on each branch line of longline fishing gears corresponding on the depth of ALB caught.

\section{Hook Depths Estimation}

In the measurement of depth of the hook, there are many factors which affect, among other things: the amount of basket that is used, total length of the main line, length of branch line, length of float line, the speed of the mainline thrower to speed of vessel, total time for settings and current factor as a correction factor. The depth of the hook can be estimated using the formula Yoshihara (1951) referred in Suharto (1995) as follows:

$$
D=f l+b l+y_{2} B K\left\{\sqrt{\left(1+\operatorname{Cotg}^{2} \sigma\right)}-\sqrt{(1-2 j / n)^{2}+\operatorname{Cotg}^{2} \sigma}\right\} \ldots
$$

where,

D : The depth of $j^{\text {th }}$ hook (for each basket, the two hooks closest to the floats are both 
numbered 1, assuming that branchlines were hung symmetrically),

fland $b l:$ The length of float line and length of branchline, respectively.

BK : The length of mainline in unit basket,

$N \quad$ : The number of branchline in unit basket.

$J \quad:$ Number of hooks position

$\sigma \quad:$ The angle between horizontal line and tangential line of the mainline at connecting points of mainline and floatline.

and:

$$
K=\frac{V k \times T s}{B K \times \sum b}
$$

$K$ : The sagging ratio

$V k$ : Speed of the mainline thrower to speed of vessel (m/hours),

Ts : Setting time,

$B K$ : The length of mainline in unit basket $(\mathrm{m})$

$\sum b$ : Number of basket in used.

The relationship between the value of K, ó and ó Cotg2 can be seen in Table 1.

Table 1. The relationship between the value of $K, \sigma$ and $\sigma \operatorname{Cotg}^{2} \sigma$

\begin{tabular}{ccc}
\hline $\boldsymbol{K}$ & $\boldsymbol{\sigma}\left(^{\mathbf{0}}\right)$ & $\boldsymbol{C o t g}^{2} \boldsymbol{\sigma}$ \\
\hline 0.902 & 40 & 1.2767 \\
0.847 & 50 & 0.7038 \\
0.769 & 56 & 0.4727 \\
0.725 & $60^{0} 30^{0}$ & 0.3300 \\
0.703 & 65 & 0.2077 \\
0.661 & 68 & 0.1630 \\
0.540 & 72 & 0.1331 \\
0.000 & 90 & 0.0000 \\
\hline
\end{tabular}

\section{Environmental Data}

The physical and biological parameters included Temp, Sal and Chl, were used to describe the oceanographic conditions at and around the ALB fishing grounds. The units of Temp, Sal and Chl, were ${ }^{\circ} \mathrm{C}$, psu and $\mathrm{mg} / \mathrm{m}^{3}$, respectively. This data obtained from the 3-D INDESO Ocean Model (www.indeso.web.id) with a horizontal resolution of $1 /$ $12^{\circ}$ and 50 vertical layers with increased resolution near the surface. Both daily Temp and Sal derived from INDO12 physical model (Tranchant et al., 2015). A daily Chl, according to the mass concentration of diatoms (DCHL) and flagellates (NCHL), derived from INDO12 biogeochemical model (Gutknecht et al., 2015). All the environmental variable have the same period with the fishery data and were matched corresponding to the positions (latitude and longitude) and the depth of ALB caught in monthly average.

\section{Generalized Additive Modeling}

Sub-surface ALB abundance and environmental data were then compiled over the 2014-2015 period on a $1 \times 1^{0}$ spatial grid each depth of ALB caught with monthly temporal resolution. GAM models were used to assess the influence of environmental variables on potential ALB abundance. The advantage of this statistical model is that it allows for analysis of nonparametric relationships and extends the use of additive models to data sets that have non-Gaussian distributions, such as Binomial, Poisson, and Gamma distributions. GAM model was created in R Studio version 3.0.2 software (R Core Team, 2015), using the gam function of the 'mgcv package'(Wood, 2006), with the number of ALB as a response variable and Temp, Sal and Chl as predictor variables. GAM models in the form of Eq. (1) were applied:

$$
g(\mu i)=a_{b}+f_{1}\left(X_{1 i}\right)+f_{2}\left(X_{2 i}\right)+f_{3}\left(X_{3 i}\right)+. . . f_{n}\left(X_{n i}\right) \cdots
$$

where $g$ is the link function, ìi is the expected value of the dependent variable (number of ALB), $a_{0}$ is the model constant, and $f_{n}$ is a smoothing function of the $X_{n}$ (which corresponds to the environmental variable in this study) (Wood, 2006).

The number of ALB caught data distribution was right skewness. Hence, to reduce right skewness, logarithmic transformation was applied. The number "1" was added to the number of ALB caught before log-transformation to avoid the singularity of low values for ALB. Seven models were constructed from the simplest form by using only one independent variable (i.e., Temp, Sal and Chl) and combinations of variables (i.e., Temp + Sal, Temp + Chl, Sal + Chl, and Temp + Sal + Chl) as listed in Table 2. For example, $X_{1 i}$ correspond to Temp in model 1 ; in model 7 , $X_{1 i}$ corresponds to Temp, $X_{2 i}$ corresponds to Sal, and $X_{3 i}$ corresponds to $\mathrm{Chl}$. These models were evaluated based on the significance level of predictors ( $P$-value), deviance explained (DE), and the Akaike information 
criterion (AIC) value (Mugo et al., 2010). AIC and DE were used to determine the best model. The smallest value of $A I C$ and the highest value of DE were selected as the best model. As a reference, the parameters of the estimated degrees of freedom (EDF) are also listed in Table 2. The predicted number of ALB was compared with the observed number using linear models. The optimal values of each predictor variable (Temp, Sal, and $\mathrm{Chl}$ ) determined by GAM were used as main parameters to explain vertically abundance of ALB in EIO.

Table 2. GAM models used in this study and obtained values for P-value, percent DE, AIC value, and DF, respectively $(\mathrm{N}=188)$.

\begin{tabular}{cllcccr}
\hline No & \multicolumn{1}{c}{ Model } & Variable & P-value & DE & \multicolumn{1}{c}{ AIC } & DF \\
\hline 1 & Temp & Temperature & 0.70 & $0.08 \%$ & 130.81 & 1.00 \\
2 & Sal & Salinity & 0.03 & $7.52 \%$ & 122.49 & 4.11 \\
3 & Chl & Chlorophyll & 0.19 & $4.10 \%$ & 127.29 & 3.10 \\
4 & Temp+Sal & Temperature & 0.03 & $9.85 \%$ & 119.66 & 1.00 \\
& & Salinity & 0.00 & & & 4.09 \\
5 & Temp+Chl & Temperature & 0.21 & $4.55 \%$ & 127.60 & 1.00 \\
& & Chlorophyll & 0.12 & & & 2.70 \\
6 & \multirow{2}{*}{ Sal+Chl } & Salinity & 0.00 & $11.90 \%$ & 117.65 & 3.95 \\
& & Chlorophyll & 0.06 & & & 2.31 \\
7 & Temp+Sal+Chl & Temperature & 0.56 & $12.00 \%$ & 119.22 & 1.00 \\
& & Salinity & 0.01 & & & 3.93 \\
& & Chlorophyll & 0.35 & & & 2.17 \\
\hline
\end{tabular}

\section{RESULTS AND DISCUSSION}

\section{Results \\ Vertically Distribution of ALBand Average Temporal Variability}

The majority of the fishing operations were conducted using longline gear type depth longline which consisted of $15-17$ hook per basket (Figure 2). Vertical distributions are divided into 6 layers of depth of water, this was done based on the depth of fishing gear longline which used for ALB can reach at least depth of $400 \mathrm{~m}$. Based on the calculation of Yoshihara formula, vertical distributions of ALB caught each branch line from about depth of 50-400 meters, were mostly at a depth of 51-100 and 151-200 meters (Figure 3).

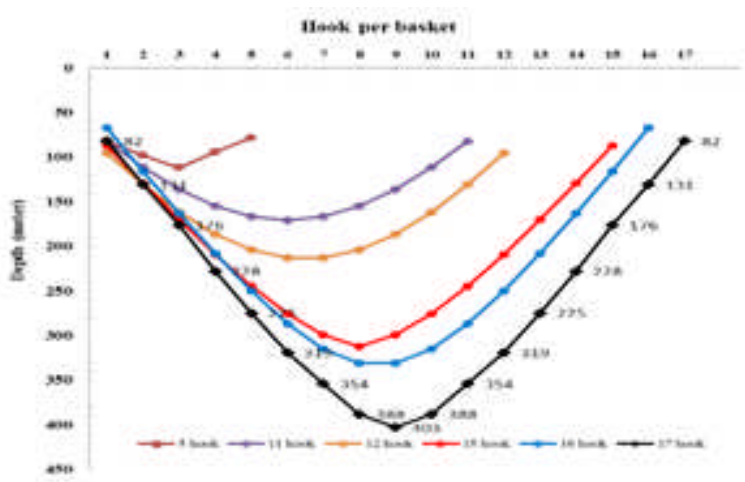

Figure 2. Estimation of hooks depth calculated using Yoshihara's formula.

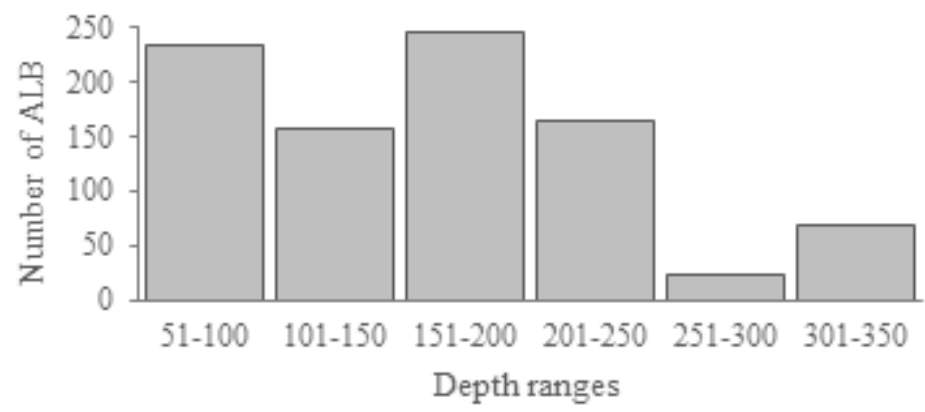

Figure 3. Number of ALB and catches by depth of hooks. 
Figure 4 shows the average temporal variability of number of ALB catches in the northwest (October March) and southeast monsoon (April - September) from 2014 to 2015. The temporal variability of number of ALB caught throughout the year was very similar.
The numbers of ALB caught tended to be high in MayJune and decreased during July to August when southeast monsoon occurred. While during northwest monsoon the of numbers of ALB caught tendend to be stable and not too much variability.

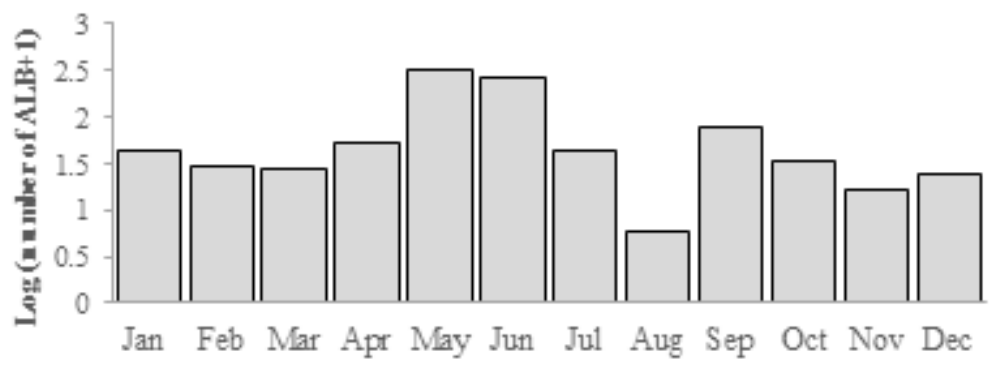

Figure 4. Average temporal variability of number of ALB catches from 2014 to 2015.

\section{Distribution of Number of ALB Caught and Environmental Data}

The distribution of number of ALB caught and the preferable environmental factors for ALB distribution can be distinguished by using the histograms shown in Figure 5. The number of ALB caught was asymmetrical distribution. The longline gears generally caught less than 5 number of ALB during this period (2014-2015). The log transformation of the number of ALB caught indicated the Poisson distribution. ALB were caught at Temp between 10.55 and $27.67^{\circ} \mathrm{C}$, with the highest frequency at $24.0-24.9$ ${ }^{\circ} \mathrm{C}$. The range of Sal for the fishing sets was 34.1436.61 psu and the preferable Sal ranged from 34.32 $34.52 \mathrm{psu}$. The Chl ranged from 0.01 to $0.49 \mathrm{mg} / \mathrm{m}^{3}$ and value of 0.01 to $0.12 \mathrm{mg} / \mathrm{m}^{3}$ was preferable for ALB vertically, with the peak at $0.01 \mathrm{mg} / \mathrm{m}^{3}$.
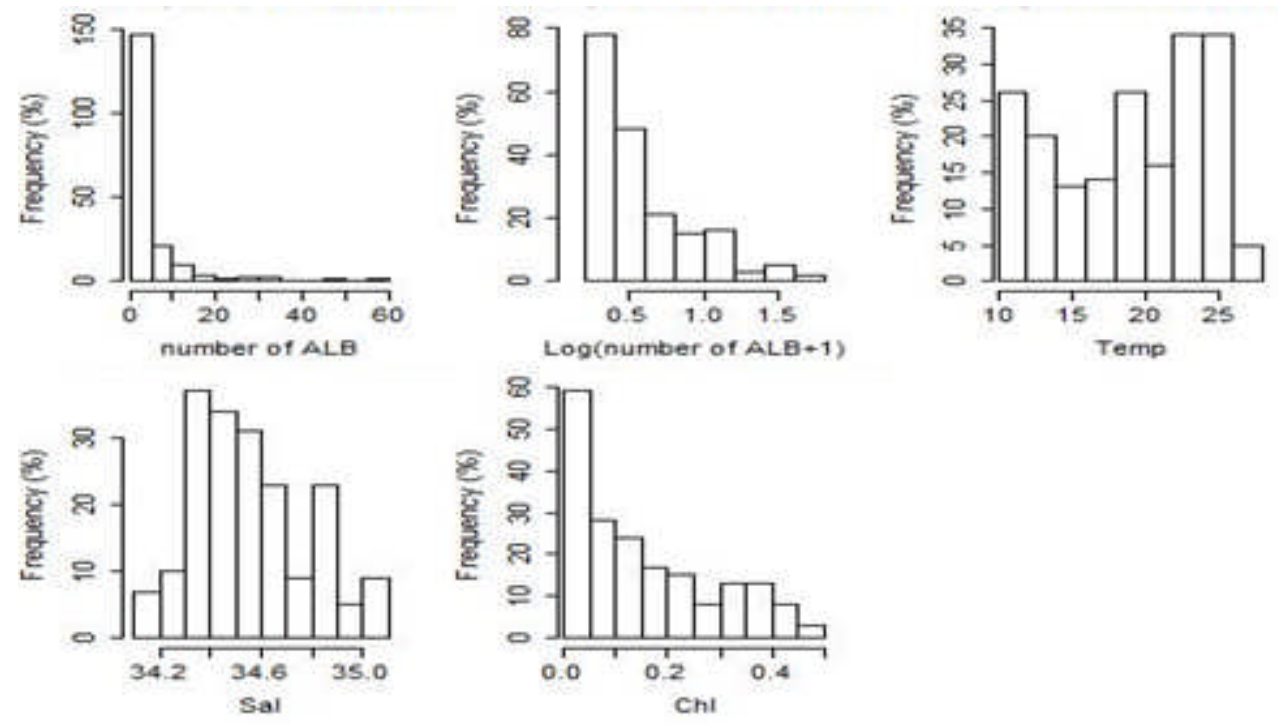

Figure 5. Histograms of number of ALB and environmental data.

\section{GAM Achiement}

Prior to examining the relationship between the ALB catches and environmental variables, the relationship between number of ALB caught and environmental variables was examined. Table 2 lists the model variable, P-value, DE, AIC, and DF for some models. The predictor variables were significant $(\mathrm{P}<$ 0.01) only in model 4 and 6 for Temp and Chl respectively, while for Sal variable were significant ( $P$ $<0.01$ ) in model 2 and 7, where Sal has highly significant $(P<0.001)$ occurred in model 4 and 6 . High significance was indicated from the lowest AIC and the highest DE. DE has the same meaning as the determination value in the linear regression. Sal showed the highest DE among the single-parameter models. Models developed from two parameters (i.e., model 6) has the lowest AIC values and the highest 
$D E$, which indicated that the combination of two parameters generated the best models. Figure 6 shows GAM plots developed to interpret the individual effect of each predictor variable on the number of ALB. A negative effect of Sal on the number of ALB was observed at salinity $>34.52 \mathrm{psu}$. There was a positive effect of salinity on the number of ALB, which was from 34.30 to 34.47 psu. ALB appeared to prefer low saline waters, current system was the cause of low

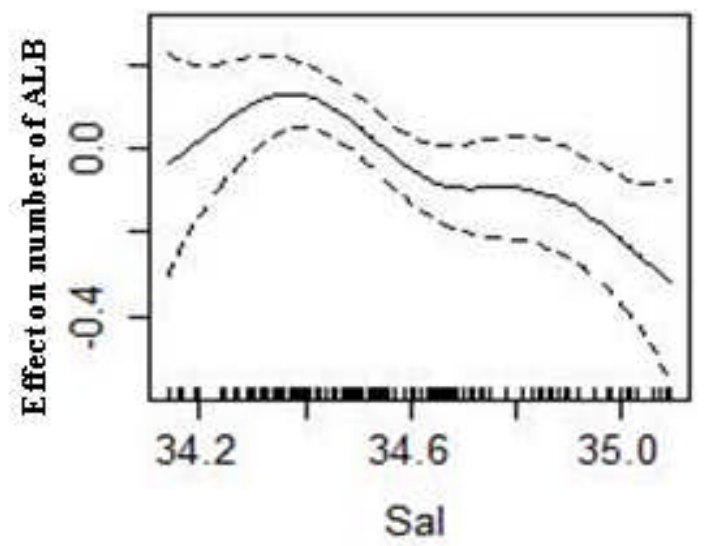

salinity bands in the areas between $10^{\circ} \mathrm{S}$ and $20^{\circ} \mathrm{S}$. As a result, the average range of $S a l$ in the Indian Ocean is not to wider in study area. A GAM plot of Chl showed a positive effect of this variable on the number of ALB caught occurred between 0.01 and $0.12 \mathrm{mg} / \mathrm{m}^{3}$ in the region of high confidence level where negative effect on $>0.13 \mathrm{mg} / \mathrm{m}^{3}$. The lower concentrated of $\mathrm{Chl}$ according to positions ALB caught.

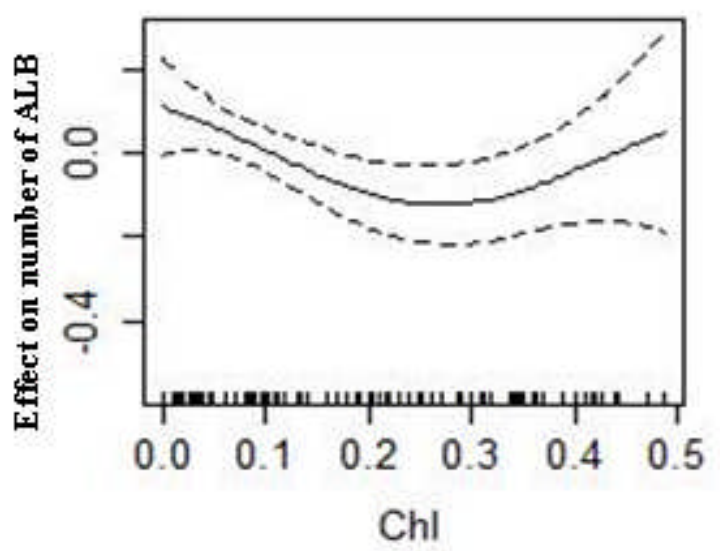

Figure 6. Effect of oceanographic variables on the number of ALB. Tick marks at abscissa axis represent the observed data points. Full line is the GAMs function. Dashed dot lines indicate the $95 \%$ confidence level.

\section{Discussion}

ALB can be classified as being a typical temperate tuna, and a typical case of highly migratory species (as bluefin and southern bluefin), doing "real" yearly extensive seasonal migrations at all ages of its life: feeding as well as spawning migrations. This species is probably also showing a homing behavior (when the adult come back in due time to the area where they were born) taking into account the apparent quite small sizes of its spawning strata (Fonteneau, 2004).

Based on spatial distribution analysis ALB were mostly found in the depth around 151 - $200 \mathrm{~m}$ (Fig. 3). This result was almost similar with Domokos et al. (2007), who was mentioned that ALB spend most of their time between 150 and $250 \mathrm{~m}$ during the daytime and between 0 and $200 \mathrm{~m}$ during the night-time, at depths coinciding with those of small local maxima in micro-nekton biomass whose backscattering properties are consistent with those of the preferred prey of ALB. Williams et al. (2014) revealed evidence that: (i) ALB tagged in the two tropical locations rarely occupied water shallower than $100 \mathrm{~m}$ during the day; (ii) remained below the MLD, with fish spending most (New Caledonia: $80 \%$, Tonga: $88 \%$ ) of the time between 150 and $250 \mathrm{~m}$ and 200-350 m, respectively; (iii) spent most (New Caledonia: 56\%, Tonga: 63\%) of the night-time between 50 and $150 \mathrm{~m}$; and (iv) maximum depths recorded by ALB tagged in New Caledonian, Tongan and New Zealand waters were $372 \mathrm{~m}, 409 \mathrm{~m}$ and $250 \mathrm{~m}$, respectively.

The effect of environmental conditions, deduced from GAMs, indicated that environmental variables influenced the numbers of ALB caught vertically. Sal (salinity) was more important than Chl (chlorophyll) or Temp (temperature) in the study area. This was indicated by Sal having the highest DE and lowest AIC in all models. In addition Salinity plays an important role for phenomenon identification of upwelling and downwelling. Wardani et al. (2014) stated that the movement of salinity with higher concentrations toward the shallower depths as an indication of the upwelling phenomenon, while the movement of salinity with higher concentrations toward a deeper depth as an indication of downwelling phenomenon. Due of this phenomenon allegedly can affect ALB abundance and related indirectly through affecting the distribution and abundance from the their prey. In this study it showed ALB catches increased in areas with relatively high Sal (34.30 to $34.47 \mathrm{psu}$ ) and decreased in the areas with Sal > 34.52 psu. Different result of previous research shows that most ALB were caught at salinity $>34.6$ psu (e.g. Roberts, 1980; Chen et al., 2005; Arrizabalaga et al., 2015; 
Novianto, 2016). Different results between this study and previous study are allegedly time period to analysis, fisheries data classification method and environmental variables data.

Chl (Chlorophyll) was the second most significant oceanographic predictor of vertically of ALB abundance in the study area. Based on the model output, the mass concentration of diatoms and flagellates expressed as chlorophyll. There was evidence that highest abundance of $\mathrm{Chl}$ is very close to surface and decreased according deeper waters. $\mathrm{Chl}$ is an index of phytoplankton biomass that provides valuable information about trophic interaction in marine ecosystem (Wilson et al., 2008), and they are a valuable proxy for water mass boundaries and upwelling events. On upwelling area, an ascension of subsurface layer to surface layer will enrich surface nutrient, which in turn will increase primary productivity and may attract various prey sources. Hendiarti et al. (2005) stated that in term of food availability, the process can attract higher trophic level organism to appear on upwelling area, while upwelling areas are potential convergence zone for plankton aggregation, attracting larger predators, such as tuna (Lehodey et al., 1997).

This study showed that ALB catches increased in areas with relatively low $\mathrm{Chl}\left(0.01\right.$ and $\left.0.12 \mathrm{mg} / \mathrm{m}^{3}\right)$ and decreased in the areas with $\mathrm{Chl}>0.13 \mathrm{mg} / \mathrm{m}^{3}$. Low $\mathrm{Chl}$ indicated that mostly ALB caught on the deeper waters. Xu et al. (2013) revealed that CPUEs of ALB is high at low chl-a levels $\left(0.14 \mathrm{mg} / \mathrm{m}^{3}\right)$ and generally decreases with higher chl-a concentrations. However, at very high chl-a concentrations ( $>20 \mathrm{mg} /$ $\mathrm{m}^{3}$ ), CPUE apparently increases to relative high levels, but relatively few observations were made at these chl-a levels. Yang et al. (2014) indicated that according to integrated habitat index (IHI) ALB foraging preference should be $160 \sim 240 \mathrm{~m}$ water layer and generally between 160 and $200 \mathrm{~m}$, where chlorophyll data used as part of $\mathrm{IHI}$ data component. According to Arrizabalaga et al. (2015), relatively low Chl waters are preferred by ALB and can tolerate a wide range of $\mathrm{Chl}$ values. Chen et al. (2005) mentioned that for immature ALB, high CPUE records correspond with higher values of chlorophyll concentration. Studies have shown that water color is an index of higher primary production, which may attract aggregations of fish. This may be especially true for feeding schools of immature albacore.

Among three environmental predictors used in the model, temperature was the least important, but was still statistically significant $(P<0.01)$ in model 4 (Table 2). Monthly average of sub-surface temperature was found tend to vary from January to December. Qu et al. (2005), stated that sub-surface temperature in the Indian Ocean was influenced by monsoon. In addition temporal distribution of sub-surface temperature in Indian Ocean part South of Java was warmer in northwest monsoon than in southeast monsoon (Sukresno et al., 2014; Hartoko, 2010). The current study showed that ALB catches varied in the temperature range with the highest frequency at 24.0$24.9^{\circ} \mathrm{C}$. Different result from Sukresno et al. (2014), in the same region concluded ALB were found with optimum temperature between $17-21^{\circ} \mathrm{C}$, where ALB avoids waters below $14 \stackrel{\circ}{\circ} \mathrm{C}$ (Arrizabalaga et al., 2015). Meanwhile Zainuddin et al. (2011), in the western North Pacific Ocean indicated that the highest concentrations of ALB were found in water of 18.5 $21.5^{\circ} \mathrm{C}$ and tended to be centered at $20^{\circ} \mathrm{C}$. Williams et al. (2014) found evidence that ALB primarily spent most (85-97\%) of their time in water $17-20^{\circ} \mathrm{C}$ both during the day and during the night, and in the two tropical locations, ALB spent most of their time (New Caledonia: $80 \%$, Tonga: $98 \%$ ) at night between 22 and $26{ }^{\circ} \mathrm{C}$, with the fish tagged in Tongan waters occupying mostly cooler waters $\left(16-21^{\circ} \mathrm{C}\right)$ during the day than those ALB tagged off New Caledonia (19-23 $\left.{ }^{\circ} \mathrm{C}\right)$.

\section{CONCLUSION}

This work provides evidence for environmental conditions can affect ALB abundance variability. Out of three environmental variables used in combining the statistical method of generalized additive model (GAM), salinity has a significant contribution to the abundance of ALB in the study area. Seven GAM models were generated with the number of $A L B$ vertical abundance as a response variable. A negative effect of salinity on the number of ALB was observed at $>34.52$ psu and the positive effect from 34.30 to 34.47 psu. In future work, increasing the number of predictor environmental variables with the high temporal resolution may improve the model of ALB abundance.

\section{ACKNOWLEDGEMENT}

The present study was founded by Ministry of Marine Affairs and Fisheries, Indonesia throughout Research Institute for Tuna Fisheries in 2014-2015. The Authors would like to express their appreciations to Dr. W.S. Pranowo and Dr. Setiawati, M.D. for valuable advice and comment, and also thank to Infrastructure Development for Space Oceanography (INDESO) for Ocean Model data, finally thank to all scientific observers for their contribution in collecting data throughout the years. 


\section{REFERENCES}

Arrizabalaga, H., Dufourb, F., Kellc, L., Merinoa, G., Ibaibarriagad, L., Chustd, G., Irigoiene, X., Santiagod, J., Muruaa, H., Frailea, I., Chiffleta, M., Goikoetxead, N., Sagarminagaa, Y., Aumontf, O., Boppg, L., Herrerah, M., Fromentini, J.M., \& Bonhomeaui, S. (2015). Global habitat preferences of commercially valuable tuna. Deep Sea Research Part II: Topical Studies in Oceanograph, 113, 102112. http://dx.doi.org/10.1016/j.dsr2.2014.07.001.

Chen, I.C., Lee, P.F, \& Tzeng, W.N. (2005). Distribution of albacore (Thunnus alalunga) in the Indian Ocean and its relation to environmental factors. Fisheries Oceanography, 14(1), 71-80.

Collette, B.B., \& Nauen, C.E. (1983). FAO species catalogue. Vol. 2. Scombrids of the world. An annotated and illustrated catalogue of tunas, mackerels, bonitos, and related species known to date. FAO Fisheries Synopsis No. 125, Vol. 2. Rome, Italy: FAO Press, 137 pp.

Domokos, R., Seki, M.P., Polovina, J.J., \& Hawn, D.R. (2007).Oceanographic investigation of the American Samoa albacore (Thunnus alalunga) habitat and longline fishing grounds. Fish. Oceanogr. 16, 555-572.

Dotson, R.C. (1976). Minimum swimming speed of albacore, Thunnus alalunga. Fishery Bulletin, 74(4), 955-960.

Fonteneau, A. (2004). An overview of Indian Ocean albacore: fisheries, stocks, and research. IOTC2004-WPTMT-02. 22pp.

Gutknecht, E., Reffray, G., Gehlen, M., Triyulianti, I., Berlianty, D. \& Gaspar, P. (2015). Evaluation of an operational ocean model configuration at $1 / 120$ spatial resolution for the Indonesian seas - Part 2: Biogeochemistry. Geosci. Model Dev. Discuss., 8, 6669-6706. doi :10.5194/gmdd-8-6669-2015.

Hartoko, A. (2010). Spatial distribution of Thunnus.sp, vertical and horizontal sub-surface multilayer temperature profiles of in-situ agro float data in Indian Ocean. J Coastal Development, 14(1), 6174.

Hastie T., \& Tibshirani, R. (1986).Generalized additive models. Stat Sci., 1:297-310.
Hendiarti, N., Suwarso., Aldrian, E., Amri, K., Andiastuti, R., Sachoemar, S.E., \& Wahyono, I.B. (2005). Pelagic fish catch around Java. Oceanography, 18(4), 112-123.

Irianto, H.E., Wudianto, Nugraha, B., Widodo, A.A., Satria, F., \& Sadiyah, L. (2015). INDONESIA National Report. Available from :http://www.iotc.org/ sites/default/files/documents/2015/11/IOTC-2015SC18-R10_Rev_1_-_Indonesia.pdf.

[IOTC], (2007). Executive summaries of the status of the major Indian Ocean tunas and billfish (albacore, bigeye, yellowfin, skipjack, and swordfish). Executive summary of the status of the albacore tuna resource. IOTC-2007-SC-03 [E]. 46 pp.

Lan, K.W., Kawamura, H., Lee, M.A., Lua, H.J., Shimada, T., Hosoda, K., \& Sakaida, F. (2012). Relationship between albacore (Thunnus alalunga) fishing grounds in the Indian Ocean and the thermal environment revealed by cloud-free microwave sea surface temperature. Fisheries Research, 113(1), 1-7. doi: 10.1016/j.fishres.2011.08.017.

Lehodey, P., Bertignac, M., Hampton, J., Lewis, A., \& Picaut, J. (1997). El nino southern oscillation and tuna in the western pacific. Nature 389, 715718.

Novianto, D. (2016). Study of albacore tuna (Thunnus alalunga) abundance using Regional Ocean Modeling System (ROMS) data in Indian Ocean. Thesis. Udayana University.

Mugo, R., Saitoh, S.I., Nihira, A., \& Kuroyama, T. (2010). Habitat characteristics of skipjack tuna (Katsuwonus pelamis) in the western North Pacific: a remote sensing perspective. Fish.Oceanogr.19, 382-396.

Nishida, T., \& Tanaka, M. (2008).General review of Indian Ocean Albacore (Thunnus alalunga).IOTCWPTe-INF03.8 pp.

Palacios, D.M., Bograd, S.J., Foley, D.G., \& Scwing, F.B. (2006). Oceanographic characteristics of biological hot spots in the North Pacific: A remote sensing perspective. Deep-Sea Research II, 53, 250-269. 
Qu, T., Du, Y., Strachan, J., Meyers, G., \& Slingo, J. (2005).Sea surface temperature and its variabilty in the Indonesian region. J Oceanography, 18(4), 50-61.

R Core Team. (2015). R:A language and environment for statistical computing. R foundation for statistical computing, Vienna, Austria; [2014 Dec 11]. Available from: http://www.R-project.org/.

Roberts, P.E. (1980). Surface distribution of albacore tuna, Thunnus alalunga Bonnaterre, in relation to the Subtropical Convergence Zone east of New Zealand. New Zealand Journal of Marine and Freshwater Research, 14(4), 373-380. doi:10.1080/ 00288330.1980 .9515879 .

Schaefer, K.M. (2001). Reproductive biology of tunas. In Tuna: physiology, ecology and evolution. Volume 19, Fish Physiology. (Eds B. A. Block and D. E. Stevens.) pp 225-269. Academic Press: New York, USA.

Setiawati, M.D., Sambah, A.B., Miura, F., Tanaka, T., \& As-syakur, A.R. (2015). Characterization of bigeye tuna habitat in the Southern Waters off Java-Bali using remote sensing data. Advances in Space Research, 55(2), 732-746. doi:10.1016/ j.asr.2014.10.007.

Solanki, H.U., Bhatpuria, D., \& Chauhan, P. (2015). Applications of generalized additive model (GAM) to satellite-derived variables and fishery data for prediction of fishery resources distributions in the Arabian Sea. Geocarto International, 1-13. doi:10.1080/10106049.2015.1120357

Song, L., Zhou, J., Zhou, Y., Nishida, T., Jiang, W., \& Wang, J. (2009). Environmental preferences of bigeye tuna, Thunnus obesus, in the Indian Ocean: an application to a longline fishery. Environmental Biology of Fishes, 85(2), 153-171. doi :10.1007/ s10641-009-9474-7.

Song, L., \& Zhou, Y. (2010). Developing an integrated habitat index for bigeye tuna (Thunnus obesus) in the Indian Ocean based on longline fisheries data. Fish. Res., 105, 63-74.

Suharto. (1995). Effect depth of hooks in tuna longline for tuna catches (Experiment orientation with MV. Madidihang in the west of Sumatra part of Indian Ocean).Bogor Agricultural Institute.
Sukresno, B., Hartoko, A., Sulistyo, B., \& Subiyanto. (2014). Empirical Cumulative Distribution Function (ECDF) analysis of Thunnus sp. using ARGO Float sub-surface multilayer temperature data in Indian Ocean South of Java. Procedia Environmental Sciences, 23, $358-367$.

Syamsuddin, M.L., Saitoh, S.I, Hirawake, T., Bachri, S., \& Harto, A.B. (2013). Effects of El NiñoSouthern Oscillation events on catches of bigeye tuna (Thunnus obesus) in the eastern Indian Ocean off Java. Fishery Bulletin, 111(2), 175-188. doi: 10.7755/FB.111.2.5

Tranchant, B., Reffray, G., Greiner, E., Nugroho, D., Koch-Larrouy, A., \& Gaspar, P. (2015). Evaluation of an operational ocean model configuration at $1 / 12^{\circ}$ spatial resolution for the Indonesian seas - Part 1: Ocean physics. Geosci. Model Dev. Discuss., 8, 6611-6668. doi: 10.5194/gmdd-8-6611-2015.

Wardani, R., Pranowo, W.S., \& Indrayanti, E. (2014). The salinity variability associated with ENSO and IOD in the Indian Ocean (south of Java up to the South Nusa Tenggara) period 2004-2010. J. Harpodon, 7(1), 9-18.

Williams, A.J., Allain, V., Nicol, S.J., Evans, K.J., Hoyle, S.D., Dupoux, C., Vourey, E., \& Dubosc, J. (2015). Vertical behavior and diet of albacore tuna (Thunnus alalunga) vary with latitude in the South Pacific Ocean. Deep Sea Research Part II: Topical Studies in Oceanography, 113, 154-169. doi: 10.1016/j.dsr2.2014.03.010.

Wilson, C., Morales, J., Nayak, S., Asanuma, I., \& Feldman, G. (2008). Ocean-color radiometry and fisheries. In: Platt, T., Hoepffner, N., Stuart, V., Brown, C. (Eds.), Why Ocean Colour?. pp. 4758. Dartmouth-Canada: The Societal Benefits of Ocean-Color Technology Reports of the International Ocean-Color Coordinating Group 7.

Wood, S. (2006). Generalized additive models: an introduction with R. Chapman and Hall/CRC Boca Raton (FL): CRC press. ISBN: 978-1-58488-474-3.

Wu, G.C.C., Chiang, H.C., Chen, K.S., Hsu, C.C., \& Yang, H.Y. (2009). Population structure of albacore (Thunnus alalunga) in the Northwestern Pacific Ocean inferred from mitochondrial DNA. Fisheries Research, 95(1), 125-131. doi: 10.1016/ j.fishres.2008.07.014. 
Xu, Y., Teo, S.L.H., \& Holmes.J. (2013). Environmental Influences on Albacore Tuna (Thunnus alalunga) Distribution in the Coastal and Open Oceans of the Northeast Pacific: Preliminary Results from Boosted Regression Trees Models. ISC/13/ ALBWG/01.17p.

Yang, J., Huang, H., Song, L., Rao, X., Wu, Y., \& Qi, G. (2014). An integrated habitat index for albacore tuna (Thunnus alalunga) in the waters near the Cook Islands based on the quantile regression method. Journal of Fihery Sciences of China, 21(4), 832-852.

Yeh, S.Y., Hui, C.F., Treng, T.D., \& Kuo, C.L. (1996). Indian Ocean albacore stock structure studies by morphometric and DNA sequence methods. IOTC Proceedings, 6th Expert Consultation on Indian Ocean Tunas. p. 258-263.

Zainuddin, M., Kiyofujia, H., Saitoh, K., \& Saitoh, S.I. (2006). Using multi-sensor satellite remote sensing and catch data to detect ocean hot spots for albacore (Thunnus alalunga) in the northwestern North Pacific. Deep Sea Research Part II: Topical Studies in Oceanography, 53(3-4), 419-431. doi: 10.1016/j.dsr2.2006.01.007

Zainuddin, M., Saitoh K., \& Saitoh S.I. (2008). Albacore (Thunnus alalunga) fishing ground in relation to oceanographic conditions in the western North Pacific Ocean using remotely sensed satellite data. Fish Oceanogr. 17, 61-73.

Zainuddin, M., Saitoh, K., \& Saitoh, S.I. (2011). Application of satellite microwave remote sensing data to simulate migration pattern of albacore tuna. International Journal of Remote Sensing and Earth Sciences, 8, 49-56.

Zainuddin, M., Nelwan, A.F., Farhum, A., Hajar, M.A.I., Najamuddin, Kurnia, M., \& Sudirman. (2013). Characterizing potential fishing zone of Skipjack Tuna during the Southeast Monsoon in the Bone Bay-Flores Sea using remotely sensed oceanographic data. J Geosciences, 4, 259-266. 